\title{
The Nutritional Content of Five Southwestern US Indigenous Maize (Zea Mays L.) Landraces of Varying Endosperm Type
}

\author{
Sarah E. Oas (D) and Karen R. Adams
}

\begin{abstract}
Any relative nutritional differences among the diverse maize (Zea mays $L$.) landraces traditionally maintained in the Greater Southwest are little understood. In this article, we investigate a range of nutritional traits of five indigenous maize landraces in the US Southwest based on different kernel endosperm types: pop, flour, flint, dent, and sweet. We present macronutrient and micronutrient values for accessions of each landrace grown in the same environmental grow-out experiment. Macronutrient values vary considerably across these endosperm accessions. Sweet and flour maize had higher values of fat and protein, whereas dent had the highest carbohydrate content. Sweet and flour maize were comparatively the best sources of micronutrients. Sweet maize yielded the highest values of potassium, thiamin, and magnesium, and flour kernels had the highest riboflavin and niacin content. These results indicate that the maintenance of diverse maize landraces had nutritional as well as ecological, symbolic, and culinary value in both the past and today. Compared to modern commercial maize standards, traditional southwestern maize landraces had a somewhat higher caloric value, many had higher vitamin and mineral content, and all accessions but dent displayed higher protein values. This suggests that southwestern maize-focused diets that included diverse landraces may have been more nutritious than previously understood.
\end{abstract}

Keywords: maize (Zea mays), nutrition, landraces, endosperm types, cuisine, US Southwest

Las diferencias nutricionales relativas entre las diversas variedades locales de maíz (Zea mays L.) que tradicionalmente se mantienen en el Gran Suroeste son poco conocidas. En este artículo, investigamos una variedad de características nutricionales de cinco variedades autóctonas de maíz en el suroeste de los EE. UU. Basadas en diferentes tipos de endospermo del grano: roseta, harinoso, pedernal, dentado y dulce. Presentamos los valores de macronutrientes y micronutrientes para las accesiones de cada variedad local cultivada en el mismo experimento de crecimiento ambiental. Los valores de macronutrientes varían considerablemente entre estas accesiones de endospermo. El maíz dulce y el harinoso tuvo mayores valores de grasas y proteínas, mientras que el dentado tuvo el mayor contenido de carbohidratos. El maíz dulce y el harinoso fueron comparativamente las mejores fuentes de micronutrientes. El maíz dulce obtuvo los valores más altos de potasio, tiamina y magnesio, y los granos del harinoso tuvieron el contenido más alto de riboflavina y niacina. Estos resultados indican que el mantenimiento de diversas variedades locales de maíz tuvo valor nutricional, ecológico, simbólico y culinario tanto en el pasado como en la actualidad. En comparación con los estándares comerciales modernos de maíz, las variedades locales tradicionales de maíz del suroeste tenían un valor calórico algo más alto, muchas tenían un contenido más alto de vitaminas y minerales, y todas las accesiones, excepto el dentado, mostraban valores de proteína más altos. Esto sugiere que las dietas centradas en el maíz del suroeste que incluían diversas variedades locales pueden haber sido más nutritivas de lo que se pensaba anteriormente.

Palabras clave: maíz (Zea mays), nutrición, variedades locales, tipos de endospermo, gastronomía, suroeste de EE. UU

$\mathrm{M}$ aize (Zea mays L.) is one of the most important crops in the world today (Nuss and Tanumihardjo 2010; US

Department of Agriculture and Foreign Agriculture Service 2019). This Mesoamerican crop, also commonly referred to as "corn"—a generic

Sarah E. Oas (sarah.oas@asu.edu, corresponding author) — School of Human Evolution and Social Change, Arizona State University, Tempe, AZ, USA

Karen R. Adams - Archaeobotanical Consultant, Tucson, AZ, USA

American Antiquity 87(2), 2022, pp. 284-302

Copyright (C) The Author(s), 2021. Published by Cambridge University Press on behalf of the Society for American Archaeology. This is an Open Access article, distributed under the terms of the Creative Commons Attribution licence (https://creativecommons.org/licenses/by/4.0/), which permits unrestricted re-use, distribution, and reproduction in any medium, provided the original work is properly cited.

doi:10.1017/aaq.2021.131 
term for cereal grains in many parts of the world - spread rapidly after it was introduced to Europe in the late fifteenth century. Maize/corn not only constitutes a major source of food globally, but it is now cultivated for domesticated animal feed and is a valuable biofuel source (US Department of Agriculture and Economic Research Service 2019). Indigenous maize provides the genetic foundation for all modern commercial maize crops. The Corn-Belt dent varieties grown commercially in the United States today were developed from a combination of a Mexican Dent landrace and "Northern Flints" that are derived from indigenous US Southwest maize landraces (Doebley et al. 1988; Swarts et al. 2017). Although the productive capabilities and nutritious properties of modern maize hybrids are well studied (e.g., Watson 2003), relatively little has been reported concerning differences in the nutritional qualities of the diverse maize landraces that remain the primary food crops for several Indigenous peoples in the US Southwest and northern Mexico.

Maize landraces are recognized and perpetuated by Indigenous communities throughout the Americas. For the purposes of this discussion, the term "landrace" is considered equivalent to "cultivated varieties" or "cultivars," which can be distinguished from one another based on many traits. For maize, these traits include (a) rates/timing of plant growth and development; (b) plant phenotypic characters (plant height, size of stalks and leaves, etc.); (c) moisture and temperature requirements, such as the number of frost-free days and accumulated growing-season heat units needed to produce mature ears; (d) daylength sensitivity/insensitivity; (e) ear size and shape and the number of kernel rows; (f) kernel color, endosperm type, and spacing between kernel rows; and (g) average kernel (grain) yield per ear or per plant (Adams et al. 2006). As will be further discussed, other definitive traits of indigenous maize landraces include taste, ease of processing, dependability, religious/ceremonial requirements, and likely others that are important to contemporary Native American groups.

The nutritional qualities of maize are influenced by a complex array of genetic, environmental, and cultural factors. Recent work has begun to address differences in the nutritional characteristics of traditional southwestern landraces, particularly in terms of agronomic and kernel color traits (e.g., Nankar et al. 2017; Ryu et al. 2013). Other studies have documented the nutritional benefits of traditional maize alkaline processing or nixtamalization (e.g., Bressani et al. 2002; Katz et al. 1974) and the mineral composition of traditional maize foods among the Hopi Tribe (Calloway et al. 1974; Kuhnlein et al. 1979). However, no studies of traditional maize landraces have systematically analyzed and compared macronutrient and micronutrient values across five recognized endosperm types-flint, flour, pop, dent, and sweet-limiting our understanding of how the adoption and consumption of diverse maize landraces contributed to the health and well-being of communities in the past and today.

The endosperm is the tissue within a kernel that provides food for the developing embryo. Flint, flour, pop, and dent maize kernels are defined by their relative amounts of flour (soft, white) versus flint (hard, corneous/translucent) endosperm, and by the internal distribution of these endosperm types within kernels. In Figure 1, flour endosperm is bright white, whereas flint endosperm is hard, translucent, and yellow in color. Pop kernels appear as an extreme form of flint kernels, with a thick, hard outer layer surrounding a small internal portion of starchy flour endosperm. At times, distinctions between these types are blurred by kernels that appear transitional between them, which are characterized as having a "flinty flour" or "floury flint" endosperm. True "dent" kernels, whose hard endosperm is distributed on both sides of a kernel, and whose interior flour endosperm extends to the top of the kernel and "dents in" as the kernel dries, are easily distinguished from "dent mimics," which are flour kernels with sunken tops caused by incomplete kernel filling when the growing season is short (Adams et al. 2006:Figure 5c). Sweet endosperm is of a completely different composition, having a translucent and wrinkled appearance when dried (Figure 1). This distinctive appearance is the product of genetic mutations preventing much of the sugar content in sweet kernels from converting to starch with maturation (Sturtevant 1899). In this article, we use "sweetcorn" 


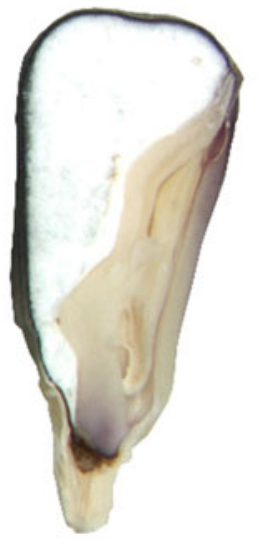

FLOUR

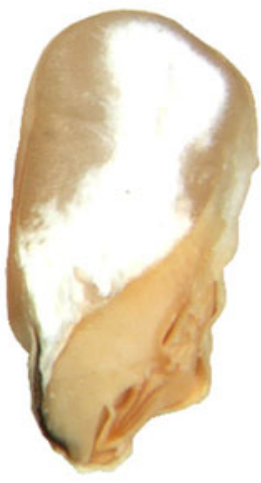

FLINT

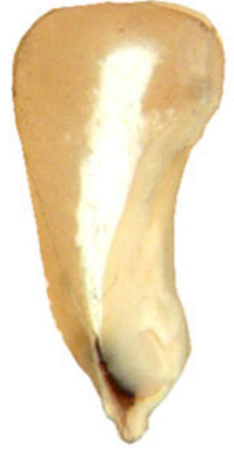

POP

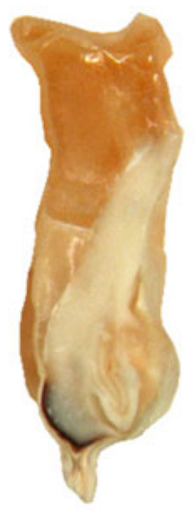

SWEET

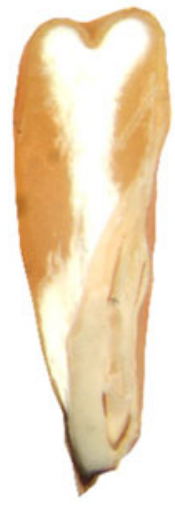

DENT

Figure 1. Distribution of endosperm in flour, flint, pop, sweet, and dent maize kernels. Kernel embryos are oriented to lower right, and different endosperm types abut each embryo and fill the remaining space.

exclusively to refer to maize landraces with this mutation and not as a reference to maize (of any endosperm type) that is harvested in the immature "green" or "milky" stage, which is often also referred to as "green corn" or "sweetcorn."

To situate this study of maize nutrition within the larger context of historic diets and nutrition in the US Southwest, we first review the research history and current understandings of maize landraces in prehispanic periods. We then review recent agronomic and nutritional analyses of indigenous southwestern maize landraces. Finally, we draw on ethnographic and experimental data to highlight the cultural and nutritional importance of maize kernel color and endosperm types and to address the nutritional characteristics of traditional maize cuisines in the US Southwest.

\section{History of Maize Research and Landraces in the US Southwest}

The history of maize in the US Southwest has long been of interest. The presence of maize in an archaeological site suggests that ancient groups either were farmers or were able to trade goods or resources for maize. Domesticated crops such as maize can provide subsistence security and surplus production, which can support sedentary communities and eventually more complex societies. The oldest-known maize macrofossils have been reported from Guilá Naquitz Cave (Figure 2) in southern Oaxaca, Mexico (Piperno and Flannery 2001; Smith 2005). Current evidence suggests that maize reached the US Southwest a little over 4,000 years ago (Merrill et al. 2009). Although several lines of archaeological data suggest that the intensity of maize agriculture varied greatly over space and through time across the US Southwest and northern Mexico (hereafter, the Greater Southwest; e.g., Hard et al. 1996), available human isotopic and coprolite data (e.g., Coltrain and Janetski 2013) indicate that maize was the dietary staple of groups in the northern US Southwest by at least the Basketmaker II period (500 BC-AD 400). By the Pueblo II and III periods (AD 1150-1300), maize likely provided $70 \%-90 \%$ of calories consumed by individuals living in the northern San Juan Region (Matson 2016).

More indirect data concerning the prehispanic production and consumption of maize comes from archaeobotanists ( paleoethnobotanists) who report and describe maize macrofossils (ears, cobs, kernels) and microfossils (pollen grains, phytoliths, starch grains) from archaeological sites. Over nearly a century, maize researchers have made observations and measurements on nearly 100 total traits of the ears, cobs, and 


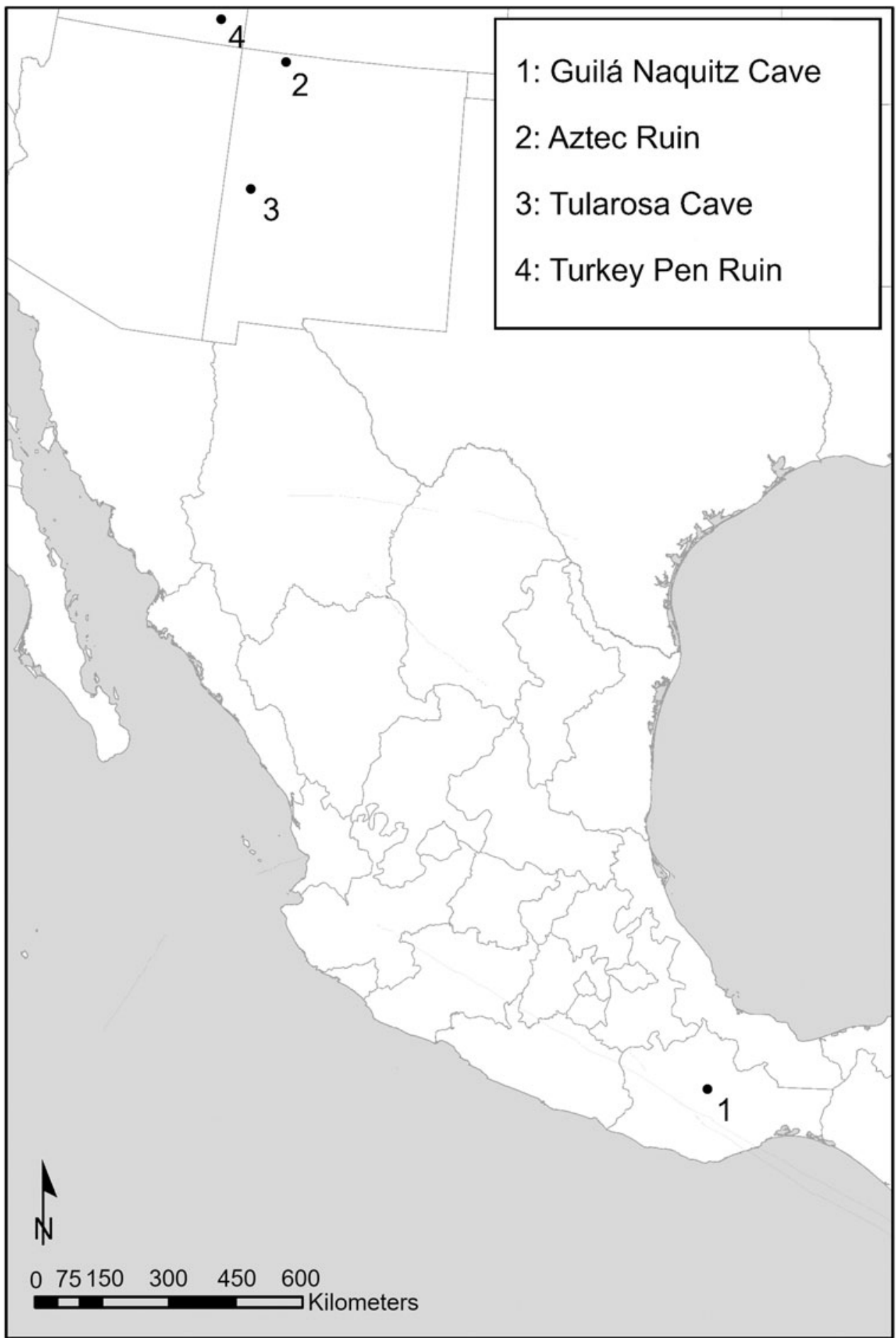

Figure 2. Map of US Southwest and Mexico with site locations listed in text. 
kernels (Martínez and Adams 2008). One longstanding goal of such studies has been to use morphological traits reliably to make distinctions between ancient maize landraces grown by farmers so as to determine when each one either entered the US Southwest from Mexico or was developed in situ. Many landrace traits cannot be determined in charred and broken archaeological specimens. Morphological ambiguity is further compounded as the larger parts of maize usually recovered from open archaeological deposits are charred and therefore likely to have experienced shrinkage or other distortions during burning (Goette et al. 1994; Stewart and Robertson 1971) and have certainly lost their color. Overall, it remains unclear which of the recommended traits are best for characterizing maize landraces (Martínez and Adams 2008), and more rigorous empirical studies of indigenous maize landraces are needed to determine which traits can be used to make distinctions between specific maize landraces in the past and trace out their histories (Adams 2015).

Despite these limitations, two routinely reported variables that are less likely to be influenced by environmental factors or morphological changes during the carbonization process are row number (the number of kernel rows on a cob) and cupule width (a cupule is a small pocket on a cob, which holds two kernels; Adams et al. 1999). Current understanding of the history of maize landraces based on morphometric surveys of these and other maize traits indicate that the earliest Archaic-age farmers in the Greater Southwest grew maize described as "small-cob" varieties (e.g., Diehl 2005; Huckell 2006:105). These small-cob varieties are thought to have had predominately flint or pop endosperm types, which is supported by analyses of ancient DNA (Jaenicke-Després et al. 2003; Swarts et al. 2017). Between approximately AD 700 and 900, several studies (e.g., Galinat 1970) document an influx of eight-rowed flour endosperm into the US Southwest. Between the twelfth and thirteenth centuries, floury endosperm landraces appear to have become the dominate landrace grown in much of the northern Southwest (Doebley and Bohrer 1983; Oas 2019:116-118).
Uncarbonized maize collections, although relatively rare, provide an important source of information about maize landraces in the past. Published descriptions of uncarbonized maize samples provide a unique view into the diversity of colors and endosperm types grown in the Greater Southwest in various times and locations (e.g., Cutler and Meyer 1965; Erwin 1934). Descriptions of the diagnostic criteria used to assign kernels to specific landraces, however, have often been inconsistently reported, and much work remains to acquire dates and fully describe kernel and cob trait characteristics for these collections. Ambiguity particularly surrounds our understandings of the location and timing of the in situ development or adoption of sweetcorn. At present, there is only one published, botanically verified (Erwin 1934) example of prehispanic sweetcorn from Aztec Ruin (LA45) that has been directly dated to cal AD 1220-1280 (Baxter 2016:274).

Uncarbonized collections also hold the greatest potential for understanding past landraces through ancient genetic research (Nistelberger et al. 2016). Recent analyses of ancient and modern US Southwest landraces provide important insights into the environmental and nutritional traits selected by farmers through time (da Fonseca et al. 2015; Jaenicke-Després et al. 2003; Swarts et al. 2017). Kernel traits, including certain starch and protein properties, were among some of the earliest traits selected by ancient farmers and were present in 2,000-year-old maize from Tularosa Cave (LA4427; JaenickeDesprés et al. 2003). The later shift toward floury maize production is also supported by genetic analyses of ancient maize from Tularosa Cave. Da Fonseca and colleagues (2015:2) document the strong selection for starch traits between cal $\mathrm{AD} 0$ and 1250, with sugaryl (sul) gene showing a more than $60 \%$ decrease in diversity in maize over time. As previously noted, genetic analyses of Basketmaker IIperiod cobs from Turkey Pen Ruin (42SA3714), Utah (Swarts et al. 2017), document the presence of primarily flint or pop varieties of maize, and several Turkey Pen samples are suggestive of high-carotenoid yellow and red kernel traitsnutritionally significant traits discussed in the following section. 


\section{Agronomic and Nutritional Traits of Maize Landraces in the Greater Southwest}

Despite the diversity of indigenous maize landraces in the US Southwest, these landraces have only recently been described following rigorous field studies by agronomists. In one study, a single landrace of Tohono O'odham flour maize was grown out under five different watering regimes over a two-year period (Muenchrath 1995). Archaeologists were able to acquire nearly 600 maize ears from this study, and they reported that the amount of water via irrigation and rainfall impacted 14 morphological traits of ears, cobs, and kernels (Adams et al. 1999). In another study, traditional Zuni blue flour maize was grown in separate well-described farmers' fields that were also monitored for a range of growth and reproductive traits (Muenchrath et al. 2002, 2017). A third agronomy study aimed to establish baseline data on a wide variety of indigenous US Southwest maize landraces; in 2003-2004, controlled grow-outs of 155 US Department of Agriculture (USDA) accessions of Native American maize took place at the New Mexico State University Agricultural Science Center fields near Farmington, New Mexico (Werth 2007). Archaeologists were able to harvest over 1,400 ears from 123 of these accessions representing a diversity of maize landraces and Native American farming groups spread across the US Southwest (Adams et al. 2006). Archaeologists first organized the landraces visually into four major morphological groups based on 10 ear and kernel traits. These morphological groups were verified via multivariate statistical analyses. Each morphological group contained maize from Indigenous groups spread across the Greater Southwest; for example, the landraces with the largest ears were grown by Havasupai, Hopi (including Moencopi), Isleta, Laguna, Navajo, Picuris, Taos, Tesuque, and Zia farmers. The landraces with the smallest ears were grown by Acoma, Hopi (including Moencopi), Mojave, Navajo, Papago, Pima/Papago, Tesuque, Hualapai, and by groups in the Chihuahua, Sinaloa, and Sonora states in Mexico. This controlled grow-out study clearly revealed substantial overlap in maize morphological traits between and among modern traditional maize landraces grown by geographically and culturally diverse Native communities.

Kernel color is both culturally (see below) and nutritionally significant. Recent work has addressed how environmental and genetic differences in kernel color affect the nutritional composition of traditional southwestern maize landraces, specifically comparing carotenoid and anthocyanin content in kernels of differing landraces (Nankar, Dungan, et al. 2016; Nankar, Scott, et al. 2016; Nankar et al. 2017; Ryu et al. 2013). Carotenoids, a group of yellow-to-red fatsoluble pigments, play an important role in human health (Johnson 2002). Yellow maize kernels are often rich in carotenoids that contribute to higher values of provitamin A (substances the body may convert to vitamin A) and that act as disease-preventing antioxidants (Johnson 2002; Kurlich and Juvik 1999). Ryu and colleagues (2013) found high carotenoid levels among several yellow- and orange-colored traditional southwestern maize varieties-for example, "Yoeme Sweet" corn, with the highest and lowest average carotenoid content associated with pop and floury endosperm types, respectively. Red, blue, or purple-black kernels that contain high values of flavonoid anthocyanins are rich sources of antioxidants and have beneficial antimicrobial and disease-preventative properties (Khoo et al. 2017). Analyses of anthocyanin level in southwestern landraces indicate that blue maize kernels contained the highest values (Nankar, Dungan, et al. 2016), and that floury and (to a lesser extent) flint endosperm types contained the highest levels, whereas dent kernels had the lowest levels (Ryu et al. 2013).

Protein levels also appear to vary by kernel color and endosperm type. Several studies suggest that traditional southwestern blue flour landraces have superior protein value and quality (Dickerson 2003; Nankar, Scott, et al. 2016; Nankar et al. 2017). Although maize is generally lacking in two essential amino acids-lysine and tryptophan-Nankar and colleagues (Nankar, Scott, et al. 2016; Nankar et al. 2017) found that floury blue southwestern landraces had higher lysine concentrations that were comparable to the opaque-2 (o2) and floury ( $f l$ and $f 2$ ) mutant genotypes that have long been used to breed maize varieties with higher lysine 
content (Azevedo et al. 2003; Mertz et al. 1964). It remains unclear, however, the extent to which the floury endosperm phenotype of southwestern blue maize accessions shares a similar genetic basis with these opaque and floury mutants. In addition to genetic differences, cultural harvest, storage, processing, and cooking practices also have significant roles to play in the bioavailability of protein and other nutrients in maize foods. We address several of these practices from the Greater Southwest in the following sections.

\section{Cultural Significance of Maize Kernel Color}

The motivations and benefits of maintaining cultivar color are multifaceted and can be understood along several lines, including ecological (e.g., managing risk of agricultural failure), ceremonial or social (e.g., symbolism, ceremonial obligations), culinary (e.g., food preferences, dietary variety), and, as we argue in this article, enhanced nutrition (Ford 1980; Rea 1997; Whiting 1939; Xolocotzi 1985). Farmers and cooks in the Greater Southwest have carefully maintained a diverse range of maize landraces for thousands of years. Traditionally, great care is taken to not mix maize of different colors at any stage of planting, harvest, storage, and preparation (e.g., Castetter and Bell 1942; Cushing 1920; Whiting 1939). Ethnographic reports note, however, the practice of mixing a few red-sometimes streaked or stripedkernels with each maize planting for a variety of desired crop benefits (Bohrer 1994:510 511), possibly conferred by transposable elements (jumping genes; McClintock 1950). Overall, kernel color and (to a lesser degree) kernel endosperm traits are relied on by planters and cooks to guide the selection of different landraces for their ecological, ceremonial, and culinary properties.

Particularly well-documented among Puebloan groups, the color of maize carries immense spiritual and symbolic significance. Maize prepared in a wide range of forms (e.g., steamed cobs, cornmeal, breadstuffs) in all colors are essential parts of many ceremonials and social activities throughout the year (e.g., Cushing 1920; Ford 1980; Parsons 1939). More generally, symbolic associations between white, yellow, red, blue, purple/black, and speckled maize and the major recognized cardinal directions (north, south, east, west, upper, lower) are maintained by Puebloan and other groups across the Greater Southwest (Castetter and Bell 1942; Ford 1980; Parsons 1939; Whiting 1939). White maize has especially important associations with the direction east and the sun, and both whole cobs and prayer meal of ground white kernels are ceremonially important materials among many Puebloan groups (e.g., Curtin 1968; Parsons 1939). Corn maidens and kachinas are also often associated with specific colors or landraces of maize and different colored wafer breads (e.g., Cushing 1920; Ford 1980; Parsons 1939). At Zuni Pueblo, Cushing (1920:36) describes corn maidens as ranging from eldest to youngest; yellow, blue, red, white, speckled, black, and finally sweetcorn.

Historic and ethnographic sources provide a limited view into the practices and perspectives of the women who traditionally took responsibility for most food processing, storage, preparation, and cooking activities. However, color, texture, and flavor of maize foods were central to cuisine and factored directly into annual decisions about the varieties of maize being grown and prepared. In addition to selecting maize of the correct color, numerous plant and mineral additives were used by cooks to produce maize foodstuffs in a range of colors. For example, ethnographic accounts indicate that plants such as pigweed (Amaranthus sp.) were used to color a variety of maize dishes red and that these plants were often cultivated or encouraged in gardens for this purpose (Sauer 1950; Stevenson 1915). Women also traditionally made a range of alkaline solutions composed of slaked limestone or culinary ashes that were used to create or enhance a desired blue-green color in numerous maize dishes (Beaglehole 1937; Cushing 1920). Consequently, in the US Southwest, not only are alkaline solutions recognized as being useful in modifying the texture of foods (i.e., striping the "skin" from kernels) when preparing dishes such as posole or bread dough but also are commonly used by cooks as food dyes. For this reason, the alkaline processing of maize in the US Southwest should be considered not only with respect to its nutritional effects but also as part of a larger suite of valued cultural 
food preparation practices (i.e., cuisine) that allowed cooks to produce a variety of distinct blue-green and other colored maize foods.

\section{Cultural Significance of Maize Endosperm Types}

Maize endosperm distinctions are also culturally valued and recognized for having diverse storage, processing, and culinary characteristics. Sweetcorn landraces are frequently consumed in the summer as green corn after roasting, parching, or boiling (e.g., Castetter and Bell 1942; Cushing 1920; Elmore 1940). Pop kernels, which explode when heated, are typically prepared by toasting and parching and are often consumed as a snack food (e.g., Beaglehole 1937; Cushing 1920; Xolocotzi 1985). Given that pop kernels are composed almost entirely of hard corneous endosperm, they are most resistant to predation by insects and small animals and capable of relatively long storage. Flint kernels are also somewhat resilient to insect predation, although they required much more labor and appropriate technologies to process into flour (Adams 1993). Flint kernels, however, are ideal for stews such as hominy because the kernels better retain their shape and texture after prolonged soaking and boiling (Briggs 2015). In contrast, flour kernels must be carefully defended from insects and other animals, and they are prone to spoilage. However, traditional southwestern floury landraces are more suitable for making maize breads because they are easily ground and their starch pasting (cook time) and gelatinization properties make them ideal for tortilla making (Chimimba et al. 2019). Dent kernels, composed of both flint and flour endosperm, would offer the advantages of both.

\section{Nutritional Characteristics of Traditional Maize Foods}

When added to maize batters and flours, traditional additives such as culinary ash significantly improve the nutritional quality of foods. Numerous studies have documented the nutritional importance of the alkaline, or nixtamal, process of treating maize with an alkaline solution either through the addition of culinary ash (potassium or sodium hydroxide) or lime (calcium hydroxide; e.g., Bressani et al. 2002;
Calloway et al. 1974; Katz et al. 1974; SernaSaldivar et al. 1990). Alkaline processing produces several desirable culinary and nutritionally beneficial effects, including (1) facilitating the removal of kernel pericarps and enabling starch gelatinization, a critical texture change required for producing breads such as tortillas; (2) inhibiting or controlling the growth of harmful mycotoxins; (3) dramatically increasing the calcium content of maize foodstuffs; (4) acting as a color "fixer" or enhancer for blue-green maize foods; (5) increasing the bioaccessibility of normally bound nutrients in maize kernels (especially niacin); and (6) improving the quality of protein particularly in terms the bioavailability of essential amino acids lysine and tryptophan. The last two are perhaps the most critical in terms of benefits conferred to prehispanic diets.

The extent of these alkaline processing effects depends to some degree on the amount of alkaline material used, the extent of soaking in the alkaline solution, and whether the maize is rinsed or washed off after the alkaline solution is added (Bressani et al. 2002). Decisions to retain or discard processing and cooking water particularly affect the mineral and water-soluble-vitamin content of alkaline-processed maize foods. Although traditional staple maize recipes such as posole typically involve soaking maize in an alkaline solution and then thoroughly rinsing it (see Beck 2001), many of the traditional mush, dumpling, and paper-bread recipes of groups in the northern US Southwest involve dry-grinding maize and adding the alkaline solution directly to the batter prior to cooking (e.g., Beaglehole 1937; Cushing 1920).

The micronutrient content of maize foods also varies depending on the specific alkaline recipes and the technologies employed to process and cook the maize. Analyses of culinary ashes traditionally used by the Hopi Tribe (Calloway et al. 1974) made from green four-wing salt bush (Atriplex canescens [Pursh] Nutt.) or bean (Phaseolus sp.) vines indicate that these contribute substantially to the mineral content of foods, particularly in terms of iron and zinc (Calloway et al. 1974:206). Other important sources of mineral supplementation to consider include the use of groundstone equipment (especially those made from limestone), the chemical composition 
of local sources of salt, the use of limestone in stone boiling maize, and even the chemical composition of ceramic cooking wares (Calloway et al. 1974; Ellwood et al., 2013; Kuhnlein 1981; Kuhnlein et al. 1979).

In addition to alkaline processing, ethnographic accounts and experimental studies suggest that the consumption of green corn (which may reference sweetcorn landraces or immature field corn of other endosperm types) and the consumption of corn fungus-or smut (Ustilago maydis) — are also nutritionally advantageous (Adams et al. 2015; Battillo 2018; Brenton 2003). Roasting or boiling harvests of green and/or sweet maize are well documented ethnographically among the Tohono O'odham, Hopi, Navajo, Zuni, and other groups in the Greater Southwest (e.g., Cushing 1920; Elmore 1940; Rea 1997; Whiting 1939). In the US Southwest, immature corn is also recognized as an important early harvest maize food, available after all stored crops and wild plant foods have been depleted or totally used up (e.g., Bradfield 1971:6). In higher-elevation areas, immature maize has also likely been long consumed as a strategy to reduce the risk of losing harvests to killing frosts (Cushing 1920:204; Snow 1991:83-87). Green corn refers to maize still in the "milky stage" and entering the last stages of maturation. When maize cobs and kernels have reached near full size, the sugars within kernels quickly begin to convert to starch, and the niacin present becomes biochemically bound (Wall et al. 1987). Green maize consumed when fresh or roasted, but also when either boiled or parched and dried, has a higher protein value and quality, and it has greater bioavailability of niacin, potassium, and other micronutrients (Carter and Carpenter 1982; Pak et al. 1975). Roasting also "fixes" the sugar content in the immature kernels, providing a sweeter taste and further inhibiting the growth of harmful microorganisms (Brenton 2003:23). Finally, the consumption of corn smut, roasted on the ear, boiled, or ground with dried maize is a widely recorded practice across the US Southwest (e.g., Castetter and Bell 1942; Dahl 1990; Reagan 1929 Stevenson 1915). Corn smut, although inherently damaging to some of a maize harvest, provides an excellent source of high-quality protein, with lysine content more than four times as abundant as that found in maize protein (Batillo 2018).

\section{Methods}

We evaluated five samples of maize kernels representing the five endosperm types, including blue flour, yellow flint, white/yellow pop, white/ clear sweet, and yellow dent landraces of maize (Figure 3; Table 1). The five landrace samples were obtained from the Maize of American Indigenous Societies (MAÍS) Southwest controlled grow-outs at the New Mexico State University Agricultural Science Center fields in 2004 (Adams et al. 2006; Werth 2007). These maize accessions were originally provided by the USDA Plant Introduction Station in Ames, Iowa (see accession numbers in Table 1). By using maize from the same grow-out-experiment field location for this study, environmental variables (e.g., elevation, fertilization, photoperiod, temperature, local precipitation, etc.) that were found to significantly influence kernel traits in previous studies (e.g., Ryu et al. 2013) can be ruled out as contributors to differences in the nutritional content of accessions examined for this study.

For each of the five samples, $300 \mathrm{~g}$ of dried kernels were shelled by hand for evaluation. Kernels were selected only from cobs that held one predominant kernel color. In addition, 50 kernels of each sample were randomly selected and bisected to verify endosperm type. All accessions were submitted to the Food Product and Safety $\mathrm{Lab}$ at the University of Arizona School of Animal and Comparative Biomedical Sciences, Tucson, for biochemical compositional trait analysis. Each sample of dried kernels was milled and chemically analyzed to provide standard nutritional panel information about macronutrients. Fatty acid and protein components were determined using Association of Official Chemists International (AOAC) official methods 920.39 and 979.09. Ash content was determined using American Society for Testing Materials International (ASTM) standard tests D2584, D5630, and ISO 3451. Moisture content was determined using AOAC approved method 950.46. Vitamin and mineral contents were analyzed at Great Lakes Scientific Laboratory, Stevensville, 


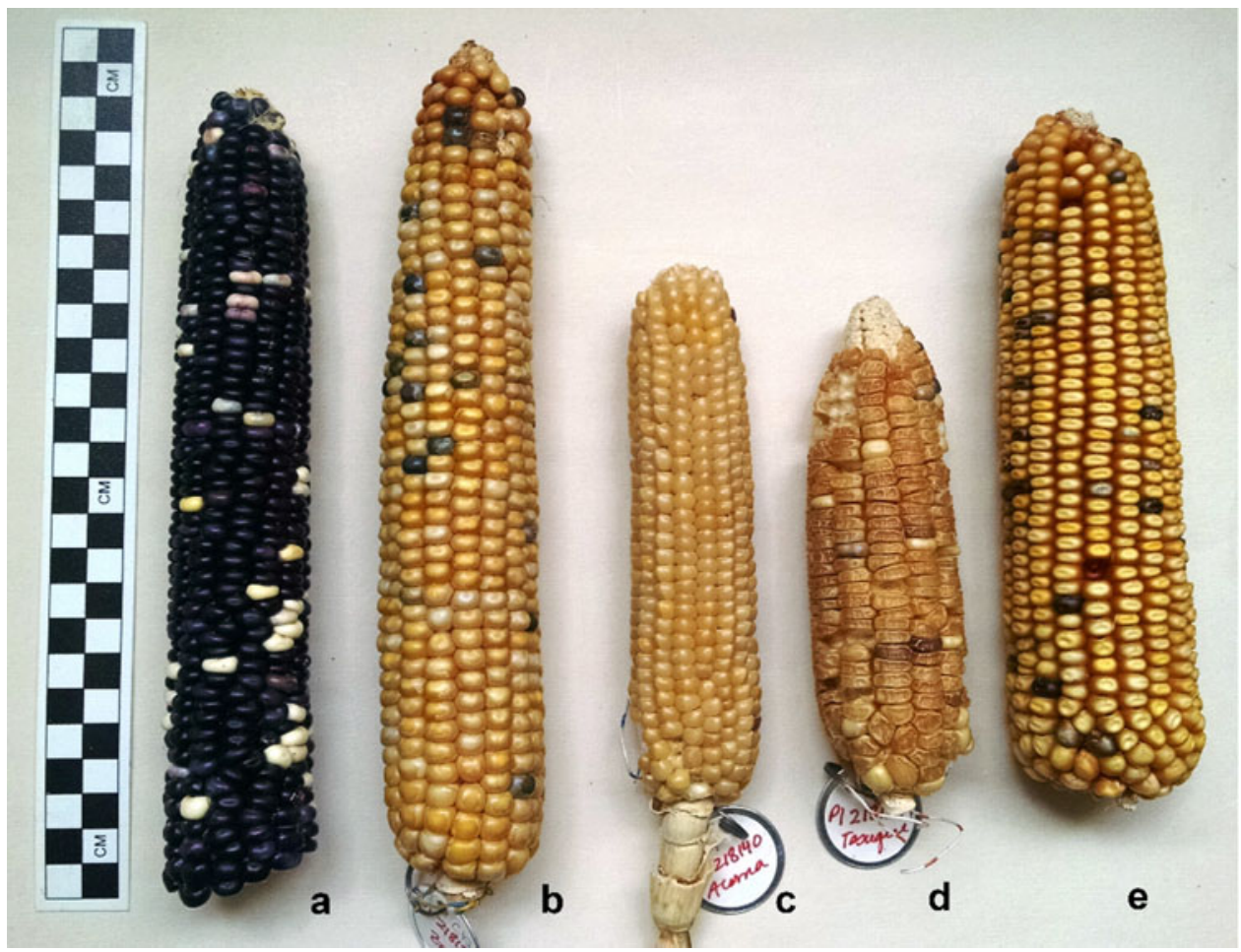

Figure 3. Representative maize cobs of each landrace accession: (a) Santo Domingo Blue Flour, (b) Zia Yellow Flint, (c) Acoma White/Yellow Pop, (d) Tesuque White/Clear Sweet, and (e) San Felipe Yellow Dent.

Michigan. Calcium, iron, potassium, zinc, and magnesium were determined using AOACapproved method 985.35. Vitamin A content was analyzed using saponification (Ball 2000) and AOAC official method 2001.13 (modified), whereas vitamin $\mathrm{C}$ content was analyzed with high-performance liquid chromatography (HPLC; Rizollo et al. 1984). B vitamins thiamin and riboflavin were analyzed using AOAC official methods 942.23, 981.15, and 970.65 (modified). Niacin content was analyzed using AOAC approved methods 944.13 and 960.46 .

\section{Macronutrients}

Carbohydrates, largely contained in the kernel endosperm, constitute the major chemical component of maize kernels, followed by protein and fat. Total carbohydrate content for each of the five southwestern landraces averaged $80.4 \mathrm{~g}$ carbohydrate/100 g of kernels (sd 3.51; Table 2). Dent kernels yielded the highest carbohydrate values, whereas the floury accession yielded the lowest. The total carbohydrate content of each of the southwestern maize accessions is slightly

Table 1. Maize Accessions Submitted for Nutritional Analysis.

\begin{tabular}{llccl}
\hline Endosperm & \multicolumn{1}{c}{ Color } & USDA Plant Accession No. & MAÍS Plot Number & \multicolumn{1}{c}{ Provenience } \\
\hline Flour & blue & 219156 & 1028 & Santo Domingo Pueblo \\
Flint & yellow & 218188 & 1039 & Zia Pueblo \\
Pop & white/yellow & 218140 & 1012 & Acoma Pueblo \\
Sweet & white/translucent & 218134 & 1006 & Tesuque Pueblo \\
Dent & yellow & 218154 & 1026 & San Felipe Pueblo \\
\hline
\end{tabular}


higher than reported for the commercial USDA standard. Among the five accessions, average sugar content was $1.8 \mathrm{~g}$ sugar/100 $\mathrm{g}$ (sd 0.84). Among the southwestern accessions, dent and flint kernels had the lowest sugar content, and the floury endosperm sample had the highest, containing three times the sugar found in dent and flint kernels.

Protein content for the five southwestern kernel accessions averaged $10.4 \mathrm{~g}$ protein/100 $\mathrm{g}$ (sd 1.52). Dent had the lowest protein content, whereas the flour kernels had the highest values with a notable $12 \mathrm{~g}$ protein/100 g. Each southwestern accession, excluding dent, had higher protein content than the commercial USDA standard (Table 2).

Fat, contained as oil in the kernel embryo, averaged $2.6 \mathrm{~g}$ fat $/ 100 \mathrm{~g}$ (sd 1.82) for all southwestern maize accessions. Sweet and flour endosperm kernels yielded the highest fat content, with values comparable to commercial maize varieties, whereas flint and dent kernels had the lowest values. That sweetcorn yields the highest fat content confers an unexpected dietary advantage that makes early harvest roasted "immature" sweetcorn even more nutritious than previously understood.

Total calorie estimates for the five traditional endosperm types averaged $388 \mathrm{kcal} / 100 \mathrm{~g}$ (sd 8.40). Dent and flint accessions yielded the lowest caloric density, and sweet kernels had the highest-400 kcal/100 g-due to their higher fat content (fat provides more than twice the calories of carbohydrates per gram). All southwestern accessions yielded a higher energy density than the approximately $360-365 \mathrm{kcal} /$ $100 \mathrm{~g}$ value calculated for traditional Central American and modern hybrid yellow and white maize (Table 2; Leung and Flores 1961).

\section{Micronutrients}

Micronutrients are essential vitamin and mineral substances that humans require in small quantities for healthy bodily development and maintenance. Given that the body does not manufacture them, these nutrients must be obtained through diet. In this article, we analyze the values of 11 micronutrients for each endosperm accession (Table 2). We analyzed five vitamins: thiamin (vitamin B1), riboflavin (vitamin B2), niacin (vitamin B3), vitamin A, and vitamin $\mathrm{C}$ (ascorbic acid). We also analyzed six minerals: calcium, iron, magnesium, potassium, sodium, and zinc. Table 2 provides additional information on vitamins and minerals, noting when a serving of maize provides more than $10 \%$ or $20 \%$ of World Health Organization (WHO) recommended daily intake (RNI). Additional methodological details for the RNI calculations are available in Supplemental Text 1 and Supplemental Table 1.

\section{Vitamins}

In this study, we examined the content of three water-soluble B vitamins-thiamin, riboflavin, and niacin-substances that are largely concentrated in the endosperm and embryo of kernels. The southwestern accessions averaged $0.55 \mathrm{mg}$ thiamin/100 g serving (sd 0.26), making each landrace an excellent source of thiamin. The pop kernels yielded the highest thiamin content of the southwestern landraces-more than double the values of other landraces and commercial maize (Table 2). Riboflavin content was lowest in the southwestern dent, flint, and pop kernels, ranging from 0.05 to $0.1 \mathrm{mg}$ riboflavin $/ 100 \mathrm{~g}$; these kernel types contain the least amounts of flour endosperm. Modern hybrid maize and the southwestern sweet kernel accession had somewhat higher values (Table 2). Most notably, the southwestern flour kernel had four times the riboflavin content of both other southwestern and the reported commercial standards: $0.8 \mathrm{mg}$ riboflavin/100 g. Niacin values across all southwestern accessions averaged $1.45 \mathrm{mg}$ niacin $/ 100 \mathrm{~g}$ (sd 0.35 ), which are similar to those reported for traditional maize varieties from Central and South America (1.9 mg niacin $/ 100 \mathrm{~g}$; Leung and Flores 1961) but lower than the USDA standard (Table 2). Assuming full bioavailability, only the southwestern sweet and flour kernel accessions would be considered "good" (i.e., $>10 \% \mathrm{RNI}$ ) niacin sources.

Vitamin $\mathrm{C}$ and A content was also examined. As expected for cereal grains, none of the accessions were significant sources of vitamin $\mathrm{C}$. The content of fat-soluble vitamin $\mathrm{A}$ in each of the southwestern landraces was also lower than the reported USDA standards for commercial 
maize. The results of this study are comparable to the average levels previously published for traditional southwestern landraces (Ryu et al. 2013).

\section{Minerals}

Most kernel mineral content (approximately $80 \%$ ) is stored in the embryo of the kernel (Earle et al. 1946). Maize, like many cereal crops, does not provide a good source of dietary calcium without additional alkaline processing. Across each southwestern accession, calcium values averaged $2.2 \mathrm{mg}$ calcium $/ 100 \mathrm{~g}$ (sd 1.1). Dent kernels yielded the highest calcium content, whereas flour kernels had the lowest. Each southwestern accession had lower calcium values than reported for commercial maize (Table 2). Maize does not contribute much dietary iron both because of its relatively low values-averaging $1.72 \mathrm{mg}$ iron/100 g (sd 0.38) —and because dietary iron is only available in the less bioavailable nonheme form in plant foods (as opposed to the heme form, which is available in animal foods). The southwestern accessions had similar iron content. Dent kernels yielded the lowest iron values, whereas pop kernels had the highest iron content. Each southwestern accession yielded iron values lower than commercial maize.

Average potassium levels for the southwestern accessions were $353.2 \mathrm{mg}$ potassium/ $100 \mathrm{~g}$ (sd 61.19), higher than reported for commercial maize (Table 2). Among the southwestern endosperm types, dent kernels had the lowest potassium levels, whereas sweet endosperm kernels had the highest, with $445 \mathrm{mg}$ potassium $/ 100 \mathrm{~g}$. Magnesium values averaged $136.2 \mathrm{mg}$ magnesium/100 g (sd 20.36) for the southwestern accessions, comparable to the commercial standard. Southwestern dent kernels had the lowest values, whereas sweet kernels had the highest magnesium content. Sodium values averaged $43 \mathrm{mg}$ sodium $/ 100 \mathrm{~g}$ (sd 6.71). Southwestern pop kernels had the highest sodium values, whereas sweet kernels had the lowest. Commercial maize and southwestern dent yielded the same sodium value, whereas each of the other southwestern accessions had somewhat higher sodium content. Finally, zinc values among the southwestern accessions averaged $1.89 \mathrm{mg}$ zinc/100 g (sd 0.58), with pop yielding 


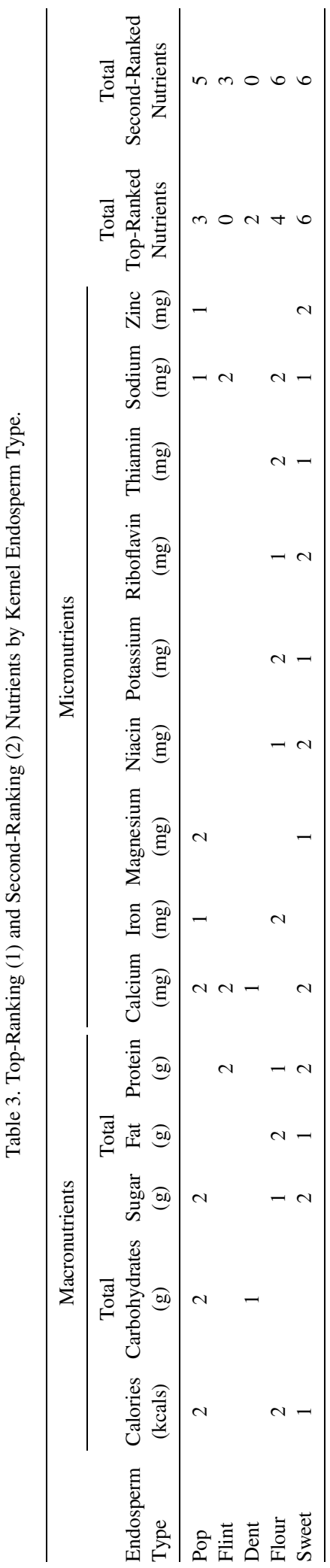

the highest values and dent yielding the lowest. Only southwestern pop kernels yielded higher zinc values than commercial maize (Table 2).

\section{Discussion}

The results of this analysis indicate that nutritional content varies among the indigenous southwestern maize endosperm types. The two top-ranking endosperm types for each macro and micronutrient are displayed in Table 3. In terms of providing the highest values of the most nutrients, sweetcorn-as a recognized endosperm type-appears to contain the most nutritional value, followed by flour and pop corn. Flint maize has the fewest top-ranking levels of nutrients of all endosperm types examined here.

Although many of the differences in nutritional content among the endosperm types are small, they would still have dietary significance for farming societies. Small differences that improve the nutrient content of dietary staples such as maize have potentially large effects on nutrition and health, something that has motivated biofortification efforts in recent decades (Nuss and Tanumihardjo 2010). This study reveals that certain endosperm types offer superior sources of some macronutrients and micronutrients. For example, flour and sweet kernels provide twice the fat content, and flour kernels provide four times the riboflavin content of the other endosperm types. The higher macronutrient and micronutrient content of different southwestern maize endosperm types, and the higher lysine content reported for southwestern blue flour varieties (Nankar, Scott, et al. 2016), would be particularly important with respect to maternal health, birth rates, and childhood development. Overall, our results indicate that Indigenous peoples in the Greater Southwest improved the quality of their diets by maintaining diverse landraces of maize as categorized by endosperm type.

The results of this analysis surprisingly reveal that sweetcorn appears to be the most nutritious endosperm type (Table 3). Sweetcorn ranks first or second in 12 of the 14 nutrients studied. Archaeological examples of sweetcorn are sparsely reported, although recent genetic analyses suggest a high frequency of the sweetcorn 
sul mutation in southwestern maize landraces (da Fonseca et al. 2015). Preservation issues also cannot be ruled out; sweetcorn may be less likely to preserve and of greater interest to rodents/insects. In addition, if immature maize of any endosperm type was consumed largely fresh, as it is today, these practices would decrease the likelihood of long-term preservation.

Following sweetcorn, flour maize ranks first or second for 10 nutrients (Table 3). The rapid adoption floury maize types previously associated with reduced processing (caloric) costs can now be understood to also be nutritionally advantageous in other ways. Our results indicate that the influx of floury endosperm types between AD 700 and 900 would have been important nutritionally in terms of suppling greater quantities of protein and fat as well as several micronutrients, including niacin and riboflavin. The higher fat and sugar content of flour kernels would also likely have been appreciated in terms of adding diversity to the taste and texture of maize foods.

Pop corn ranks first or second for eight nutrients, and it could be relatively easily "popped" by use of heat. Flint and dent endosperm kernels have the fewest numbers of first- and secondranked nutrients, with three and two, respectively. Both presumably have good storage qualities, and "flint" corn is the most frequently reported endosperm type in the eastern and midwestern United States (VanDerwerker et al. 2017).

More broadly, the results of this study are consonant with previous analyses documenting the relatively higher starch and protein content of southwestern blue-flour landraces compared with commercial hybrid varieties (Nankar, Scott et al. 2016). Our results further reveal that southwestern flour endosperm kernels have relatively high protein content even compared to other indigenous flint, pop, sweet, and especially dent kernel varieties. Additional analyses of the amino acid characteristics of different southwestern endosperm types are necessary to understand how the quality of protein, specifically the most limited essential amino acids, vary among these landraces.

USDA standard reference information on maize nutrition has not included the diversity of existing indigenous maize landraces. Our research aims to expand understanding by considering different endosperm types. Given the variation in nutritional content documented in this study within and between indigenous southwestern maize and commercial hybrid varieties, greater care should be taken with using modern maize nutritional values to model and interpret past diets. Efforts to model health and diet will also benefit from employing a broader array of maize nutritional traits in addition to assessing more traditional measures of acreage yield and caloric adequacy. Approaches incorporating a wider range of macronutrient and micronutrient data will be beneficial in understanding health and well-being within farming communities, particularly with respect age and gender-work that could be usefully paired with bioarchaeological, isotopic, and other archaeological analyses of health in the past.

To understand how maize fit into prehispanic diets and human health, it is also necessary to consider how the actual bioavailability of nutrients would have been affected by a range of environmental and cultural factors (i.e., foodways). Bioavailability in a nutritional context refers to the quantity of a nutrient that is available or bioaccessible to the individual consuming it. Each step in the process of producing maize foods - (1) the variety of maize grown and field conditions (e.g., elevation, irrigation, etc.); (2) the consumption of maize in different forms or maturation states (e.g., green, mature, roasted); (3) processing and preparation techniques (e.g., finely or coarsely ground, soaked in alkaline solution, etc.); and (4) cooking techniques (e.g., boiling, popping, etc.)-has implications for the nutritional content of the consumed food. Ultimately, estimating the dietary value of foods in the past is complex, and it requires addressing the contributions and interactions of multiple nutrients, tools, and chemical processes.

To achieve more sophisticated understanding of prehispanic diets and nutrition in the Southwest, more attention should be given to understanding such issues as maize storage, processing, and cooking techniques, because these significantly alter the bioavailability of many macronutrients and micronutrients. Watersoluble vitamins such as ascorbic acid, thiamin, riboflavin, and niacin are especially prone to 
loss if water used to soak or boil foods is discarded. Given the importance of alkaline processing in improving the protein quality and bioaccessibility of micronutrients in maize foods, more synthetic archaeological and experimental work should be directed toward documenting the history of these practices in the Southwest (e.g., Ellwood et al. 2013; Johnson and Marston 2020). Analyses of calcium carbonate nodules and burned limestone fragments will be important in terms of understanding preceramic alkaline processing and pot-boiling cooking techniques. The practice of consuming roasted sweet and/or green corn is especially poorly understood in prehispanic periods, even though the consumption of sweet and/or green corn would have been an excellent source of nutrients. Archaeological examinations of pit- and ovenroasting features and work with uncarbonizedmaize museum collections examining kernel and cob remains will be important for improving understandings of sweet- and green-corn consumption in the past. Finally, experimental work might allow for the development of better macrobotanical indicators for the consumption of maize in different forms in the past-for example, the presence of charred isolated maize embryos that might become detached from kernels when maize is being consumed fresh off the cob.

\section{Conclusions}

In this article, we have reviewed the differences in the nutritional composition of maize by comparing across the five traditionally recognized endosperm types, and we have discussed the importance of considering not only the biological and environmental but also the cultural factors that heavily influence diets consisting largely of maize. We argue that the maintenance of diverse landraces not only has ecological and symbolic importance but also provides more complete nutrition. Beyond the nutritional importance of color and endosperm types, environmental and cultural factors are also significant for understanding the dietary role of maize foods in the Greater Southwest. Studies of past diet and nutrition should be supplemented with experimental and archaeological analyses that assess the dietary values of maize within the broader context of foodways. Ultimately, consuming diverse landraces of maize harvested in a variety of states of maturity, and prepared and cooked in a range of ways, not only made maize foods more enjoyable for the consumer but contributed to overall healthier diets.

To further improve understandings of prehispanic maize-centered diets, future studies should seek to document and clarify temporal and spatial patterns in the use of different maize landraces with respect to kernel endosperm composition and color-two traits that are extremely important to Native groups in the US Southwest today. Revisiting, dating, and reanalyzing uncarbonized collections is critical to this work. Given that this study presents a baseline analysis of the nutritional composition of five Indigenous southwestern maize landraces, future studies should expand this work by including multiple representative landraces of each endosperm type to understand variability within samples of the same endosperm type. Finally, future studies should systematically evaluate kernel color for potential differences in nutritional traits and focus on the amino-acid content in kernels of diverse indigenous southwestern landraces defined by color and endosperm.

Acknowledgments. This work was supported by a research grant from the Graduate and Professional Student Association at Arizona State University. We are grateful to maize agronomist Dr. Deborah Muenchrath for her invaluable research on indigenous US Southwest maize landraces and to Lindsay Werth for sharing maize specimens with us from her controlled grow-out master's degree experiments cited here. We also thank Crystal Carr and the staffs at the University of Arizona Food Product and Safety Laboratory and at Great Lakes Scientific Inc. for conducting the nutritional analyses of the maize kernels. Finally, we thank four anonymous reviewers for their thoughtful feedback and suggestions for improving this manuscript. All images were created by the authors.

Data Availability Statement. Details concerning the provenience, field observations, ear and kernel characteristics, and experimental grow-out conditions of the sampled maize specimens are available in Adams et alia 2006. Maize samples from the systematic grow-out experiments are currently housed at the Arizona State Museum in Tucson, Arizona.

Supplemental Material. For supplemental material accompanying this article, visit https://doi.org/10.1017/aaq.2021.131.

Supplemental Text 1. Methodological Details for Calculating Recommended Nutrient Intake Values for Prehispanic US Southwest Populations. 
Supplemental Table 1. Recommended Nutrient Intakes (RNIs) and Daily Value Percentages for Nutrients across Kernel Endosperm Type (per $100 \mathrm{~g}$ ).

\section{References Cited}

Adams, Karen R.

2015 The Archaeology and Agronomy of Ancient Maize (Zea mays L.). In Traditional Arid Lands Agriculture: Understanding the Past for the Future, edited by Scott E. Ingram and Robert C. Hunt, pp. 15-53. University of Arizona Press, Tucson.

Adams, Karen R., Cathryn M. Meegan, Scott G. Ortman, R. Emerson Howell, Lindsay C. Werth, Deborah A. Muenchrath, Michael K. O'Neill, and Candice A. C. Gardner

2006 MAIIS (Maize of American Indigenous Societies) Southwest: Ear Descriptions and Traits That Distinguish 27 Morphologically Distinct Groups of 123 Historic USDA Maize (Zea mays L. ssp. mays) Accessions and Data Relevant to Archaeological Subsistence Models. Manuscript in possession of K. R. Adams. PDF available from Kevin Lombard, NSMU ASC Farmington. Electronic document, https://farmingtonsc.nmsu.edu/projects-results. html\#anchor_14671, accessed July 25, 2019.

Adams, Karen R., Deborah A. Muenchrath, and Dylan M. Schwindt

1999 Moisture Effects on the Morphology of Ears, Cobs and Kernels of a North American Maize (Zea mays L.) Cultivar, and Implications for the Interpretation of Archaeological Maize. Journal of Archaeological Science 26:483-496.

Adams, Jenny L.

1993 Toward Understanding the Technological Development of Manos and Metates. Kiva 58:331-344.

Adams, Jenny L., Joyce S. Rychener, and Allen J. Denoyer

2015 Las Capas Archaeological Project: Ground Stone and Maize Processing Experiments. Technical Report No. 2014-02. Desert Archaeology, Tucson, Arizona.

Azevedo, Ricardo. A., Catherine Damerval, Jacques Landry, Peter J. Lea, Cláudia M. Bellato, Lyndel W. Meinhardt, Martine Le Guilloux, et al.

2003 Regulation of Maize Lysine Metabolism and Endosperm Protein Synthesis by Opaque and Floury Mutations. European Journal of Biochemistry 270:4898-4908.

Ball, George F. M.

2000 The Fat Soluble Vitamins. In Food Analysis by HPLC, 2nd ed., edited by Leo M. L. Nollet, pp. 339. Marcel Dekker, New York.

Battillo, Jenna

2018 The Role of Corn Fungus in Basketmaker II Diet: A Paleonutrition Perspective on Early Corn Farming Adaptations. Journal of Archaeological Science: Reports 21:64-70.

Baxter, L. Erin

2016 A New Archaeological History of Aztec Ruins, New Mexico: Excavating the Archives. PhD dissertation, Department of Anthropology, University of Colorado, Boulder. Proquest (ATT 10151169).

Beaglehole, Pearl

1937 Foods and Their Preparation. In Notes on Hopi Economic Life, by Ernest Beaglehole and Pearl Beaglehole, pp. 60-71. Yale University Publications in Anthropology 15. Yale University Press, New Haven, Connecticut.
Beck, Margaret

2001 Archaeological Signatures of Corn Preparation in the U.S. Southwest. Kiva 67:187-218.

Bohrer, Vorsila

1994 Maize in Agricultural Traditions. In Corn and Culture in the Prehistoric New World, edited by Sissel Johannessen and Christine Hastorf, pp. 469-512. Westview Press, Boulder, Colorado.

Bradfield, Maitland

1971 The Changing Pattern of Hopi Agriculture. Occasional Paper 30. Royal Anthropological Institute of Great Britain and Ireland, London.

Brenton, Barrett P.

2003 Green Corn Ceremonialism and Ethnonutrition: A Case Study on the Biocultural Evolution of Maize Processing. Nutritional Anthropology 26:22-26.

Bressani, Ricardo, Juan Carlos Turcios, and Ana Silvia Colmenares de Ruiz

2002 Nixtamalization Effects on the Contents of Phytic Acid, Calcium, Iron and Zinc in the Whole Grain, Endosperm and Germ of Maize. Food Science and Technology International 8:81-86.

Briggs, Rachel V.

2015 The Hominy Foodway of the Historic Native Eastern Woodlands. Native South 8:112-146.

Calloway, Doris H., Robert D. Giaque, and F. M. Costa

1974 The Superior Mineral Content of Some American Indian Foods in Comparison to Federally Donated Counterpart Commodities. Ecology of Food and Nutrition 3:203-211.

Carter, Eric G. and Kenneth J. Carpenter

1982 The Available Niacin Values of Foods for Rats and Their Relation to Analytical Values. Journal of Nutrition 112:2091-2103.

Castetter, Edward F., and Willis H. Bell

1942 Pima and Papago Agriculture. University of New Mexico Press, Albuquerque.

Chimimba, Justin, Richard Pratt, Maria Cuellar, and Efren Delgado

2019 Quality Parameters of Masa and Tortillas Produced from Blue Maize (Zea mays sp. mays) Landraces. Journal of Food Science 84:213-223.

Coltrain, Joan Brenner, and Joel C. Janetski

2013 The Stable and Radio-Isotope Chemistry of Southeastern Utah Basketmaker II Burials: Dietary Analysis Using the Linear Mixing Model SISUS, Age and Sex Patterning, Geolocation and Temporal Patterning. Journal of Archaeological Science 40:4711-4730.

Curtin, Leonora S. M.

1968 Preparation of Sacred Corn Meal in the Rio Grande Pueblos. Southwest Museum Leaflets 31:3-15.

Cushing, Frank H.

1920 Zuni Breadstuff. Indian Notes and Monographs No. 8. Museum of the American Indian, New York.

Cutler, Hugh C., and Winton Meyer

1965 Corn and Cucurbits from Wetherill Mesa. American Antiquity 31:136-152.

da Fonseca, Rute R., Bruce D. Smith, Nathan Wales, Enrico Cappellini, Pontus Skoglund, Matteo Fumagalli, José Alfredo Samaniego, et al.

2015 The Origin and Evolution of Maize in the Southwestern United States. Nature Plants 1:Article 14003. DOI:10.1038/nplants.2014.3.

Dahl, Kevin

1990 Corn Soot Woman's Timeless Lesson: Eat Your Smut. Permaculture Drylands Journal 11:10-11,14. 
Dickerson, George W.

2003 Nutritional Analysis of New Mexico Blue Corn and Dent Corn Kernels. Guide H-233, Cooperative Extension Service, College of Agriculture and Home Economics, New Mexico State University, Las Cruces.

Diehl, Michael W.

2005 Morphological Observations on Recently Recovered Early Agricultural Period Maize Cob Fragments from Southern Arizona. American Antiquity 70:361-375.

Doebley, John, and Vorsila L. Bohrer

1983 Maize Variability and Cultural Selection at Salmon Ruin, New Mexico. Kiva 49:19-37.

Doebley, John, Jonathan D. Wendel, J. S. C. Smith, Charles W. Stuber, and Major M. Goodman

1988 The Origin of Cornbelt Maize: The Isozyme Evidence. Economic Botany 42:120-131.

Earle F. R., J. J. Curtis, and J. E. Hubbard

1946 Composition of the Component Parts of the Corn Kernel. Cereal Chemistry 23:504-511.

Ellwood, Emily C., Paul M. Scott, William D. Lipe, R. G. Matson, and John G. Jones

2013 Stone-Boiling Maize with Limestone: Experimental Results and Implications for Nutrition among SE Utah Preceramic Groups. Journal of Archaeological Science 40:35-44.

Elmore, Francis H.

1940 Ethnobotany of the Navajo. Monographs of the School of American Research 8. University of New Mexico Press, Albuquerque.

Erwin, Arthur T

1934 A Rare Specimen of Zea mays var. saccharata Found. Science 79:589

Ford, Richard I.

1980 The Color of Survival. Discovery (School of American Research, Santa Fe, New Mexico) 1980:17-29.

Galinat, Walton C.

1970 The Cupule and Its Role in the Origin and Evolution of Maize. Agricultural Experiment Station Bulletin 585. University of Massachusetts, Amherst.

Goette, Susan, Michele Williams, Sissel Johannessen, and Christine A. Hastorf

1994 Towards Reconstructing Ancient Maize: Experiments in Processing and Charring. Journal of Ethnobiology 14:1-21.

Hard, Robert J., Raymond P. Maudlin, and Gerry R. Raymond

1996 Mano Size, Stable Carbon Isotope, and Macrobotanical Remains as Multiple Lines of Evidence of Maize Dependence in the American Southwest. Journal of Archaeological Method and Theory 3:253-318.

Huckell, Lisa W.

2006 Ancient Maize in the American Southwest: What Does It Look Like and What Can It Tell Us? In Histories of Maize: Multidisciplinary Approaches to the Prehistory, Linguistics, Biogeography, Domestication, and Evolution of Maize, edited by John Staller, Robert Tykot, and Bruce Benz, pp. 97-197. Elsevier, Amsterdam.

Jaenicke-Després, Viviane, Ed S. Buckler, Bruce D. Smith, M. Thomas P. Gilbert, Alan Cooper, John Doebley, and Svante Pääbo

2003 Early Allelic Selection in Maize as Revealed by Ancient DNA. Science 302:1206-1208.

Johnson, Elizabeth J.

2002 The Role of Carotenoids in Human Health. Nutrition in Clinical Care 5:56-65.
Johnson, Emily S., and John M. Marston

2020 The Experimental Identification of Nixtamalized Maize through Starch Spherulites. Journal of Archaeological Science 113:Article 105056. DOI:10.1016/j. jas.2019.105056.

Katz, Solomon, Mary L. Hediger, and Linda A. Valleroy 1974 Traditional Maize Processing Techniques in the New World. Science 184:765-773.

Khoo, Hock Eng, Azrina Azlan, Sou Teng Tang, and See Meng Lim

2017 Anthocyanidins and Anthocyanins: Colored Pigments as Food, Pharmaceutical Ingredients, and the Potential Health Benefits. Food and Nutrition Research 61. DOI:10.1080/16546628.2017.1361779.

Kuhnlein, Harriet V.

1981 Dietary Mineral Ecology of the Hopi. Journal of Ethnobiology 1:84-94.

Kuhnlein, Harriet V., Doris H. Calloway, and Barbara F. Harland

1979 Composition of Traditional Hopi Foods. Journal of the American Dietetic Association 75:37-41.

Kurilich, Anne C., and John A. Juvik

1999 Quantification of Carotenoid and Tocopherol Antioxidants in Zea mays. Journal of Agricultural and Food Chemistry 47:1948-1955.

Leung, Woot-Tsuen Wu, and Marina Flores

1961 Food Composition Table for Use in Latin America. Interdepartmental Committee on Nutrition for National Defense-Institute of Nutrition of Central America and Panama. US Government Printing Office, Washington, DC.

Martínez, Natalia, and Karen R. Adams

2008 Archaeological Maize: A Reassessment of Traits Relevant to Distinguishing Varieties. Poster presented at the 73rd Annual Meeting of the Society for American Archaeology, Vancouver, British Columbia, Canada.

Matson, R. G.

2016 The Nutritional Context of the Pueblo III Depopulation of the Northern San Juan: Too Much Maize? Journal of Archaeological Science 5:622-631.

McClintock, Barbara

1950 The Origin and Behavior of Mutable Loci in Maize. PNAS 36:344-355.

Merrill, William L., Robert J. Hard, Jonathan B. Mabry, Gayle J. Fritz, Karen R. Adams, John R. Roney, and A. C. MacWilliams

2009 The Diffusion of Maize to the Southwestern United States and Its Impact. PNAS 106:21019-21026.

Mertz, Edwin T., Lynn S. Bates, and Oliver E. Nelson

1964 Mutant Gene That Changes Protein Composition and Increase Lysine Content of Maize Endosperm. Science 145:279-280.

Muenchrath, Deborah A

1995 Productivity, Morphology, Phenology, and Physiology of a Desert-Adapted Native American Maize (Zea mays L.) Cultivar. PhD dissertation, Department of Agronomy, Iowa State University, Ames. Proquest (ATT 9540927).

Muenchrath, Deborah A., Maya Kuratomi, Jonathan A. Sandor, and Jeffrey A. Homburg

2002 Observational Study of Maize Production Systems of Zuni Farmers in Semiarid New Mexico. Journal of Ethnobiology 22:1-33.

Muenchrath, Deborah A., Jonathan A. Sandor, Jay B. Norton, and Jeffrey A. Homburg 
2017 A Maize Experiment in a Traditional Zuni Agroecosystem. Journal of Ethnobiology 37:172-195.

Nankar, Amol N., Barry Dungan, Neil Paz, Nilusha Sudasinghe, Tanner Schaub, Omar F. Holguin, and Richard C. Pratt

2016 Quantitative and Qualitative Evaluation of Kernel Anthocyanins from Southwestern United States Blue Corn. Journal of the Science of Food and Agriculture 96:4542-4552.

Nankar, Amol N., F. Omar Holguin, Paul M. Scott, and Richard C. Pratt

2017 Grain and Nutritional Quality Traits of Southwestern U.S. Blue Maize Landraces. Cereal Chemistry 94:950-955.

Nankar, Amol N., Paul Scott, and Richard C. Pratt

2016 Agronomic and Kernel Compositional Traits of Blue Maize Landraces from the Southwestern United States. Crop Science 56:2663-2674.

Nistelberger, Heidi M., Oliver Smith, Nathan Wales, Bastiaan Star, and Sanne Boessenkool

2016 The Efficacy of High-Throughput Sequencing and Target Enrichment on Charred Archaeobotanical Remains. Nature: Scientific Reports 6:37347. DOI:10. 1038/srep37347.

Nuss, Emily T., and Sherry A. Tanumihardjo

2010 Maize: A Paramount Staple Crop in the Context of Global Nutrition. Comprehensive Reviews in Food Science and Food Safety 9:417-436.

Oas, Sarah E.

2019 Cibola Breadstuff: Foodways and Social Transformation in the Cibola Region A.D. 1150-1400. PhD dissertation, School of Human Evolution and Social Change, Arizona State University, Tempe. Proquest (ATT 13862579).

Pak, Nelly, Ita Barja, and María Angélica Tagle

1975 Chemical Composition, Protein Quality and Protein Value of Opaque-2 and Other Varieties of Maize at Different Stages of Ripening. Ecology of Food and Nutrition 4:177-181.

Parsons, Elsie Clews

1939 Pueblo Indian Religion. University of Chicago Press, Chicago.

Piperno, Dolores R., and Kent V. Flannery

2001 The Earliest Archaeological Maize (Zea mays L.) From Highland Mexico: New Accelerator Mass Spectrometry Dates and Their Implications. PNAS 98:2101-2103.

Rea, Amadeo M.

1997 At the Desert's Green Edge: An Ethnobotany of the Gila River Pima. University of Arizona Press, Tucson.

Reagan, Albert B.

1929 Plants Used by the White Mountain Apache Indians of Arizona. Wisconsin Archeologist 8(4):143-161.

Rizollo, Anna, Elisabetta Forni, and Andrea Polesello

1984 HPLC assay of Ascorbic Acid in Fresh and Processed Fruit and Vegetables. Food Chemistry 14:189199.

Ryu, Si Hwan, Lindsay C. Werth, Suzanne Nelson, Joseph C. Scheerens, and Richard C. Pratt

2013 Variation of Kernel Anthocyanin and Carotenoid Pigment Content in USA/Mexico Borderland Land Races of Maize. Economic Botany 67:98-109.

Sauer, Jonathan D.

1950 Amaranths as Dye Plants among the Pueblo Peoples. Southwestern Journal of Anthropology 6:412-415.
Serna-Saldivar, Sergio O., Maria H. Gomez, and Lloyd W. Rooney

1990 Technology, Chemistry, and Nutritional Value of Alkaline Cooked Corn Products. In Advances in Cereal Science and Technology Vol. 10, edited by Yeshajahu Pomeranz, pp. 243-307. American Association of Cereal Chemists, St. Paul, Minnesota.

Smith, Bruce D.

2005 Reassessing Coxcatlan Cave and the Early History of Domesticated Plants in Mesoamerica. PNAS 102:9438-9445.

Snow, David H.

1991 Upland Prehistoric Maize Agriculture in the Eastern Rio Grande and Its Peripheries. In Farmers, Hunters, and Colonists: Interaction Between the Southwest and the Southern Plains, edited by Katherine A. Spielmann, pp. 71-88. University of Arizona Press, Tucson.

Stevenson, Matilda C.

1915 Ethnobotany of the Zuni Indians. Annual Report of the Bureau of American Ethnology 30. Government Printing Office, Washington, DC.

Stewart, Robert B., and William Robertson III

1971 Moisture and Seed Carbonization. Economic Botany 25:381.

Sturtevant, E. Lewis

1899 Varieties of Corn. Office of Experiment Stations Bulletin 57. US Department of Agriculture, Washington DC.

Swarts, Kelly, Rafal M. Gutaker, Bruce Benz, Michael Blake, Robert Bukowski, James Holland, Melissa KrusePeeples, et al.

2017 Genomic Estimation of Complex Traits Reveals Ancient Maize Adaptation to Temperate North America. Science 357:512-515.

US Department of Agriculture

2019 National Nutrient Database for Standard Reference. Electronic document, https://fdc.nal.usda.gov/, accessed June 18, 2019.

US Department of Agriculture and Economic Research Service

2019 U.S. Bioenergy Statistics: Table 5-Corn Supply, Disappearance and Share of Total Corn Used for Ethanol. Electronic document, https://www.ers.usda.gov/dataproducts/us-bioenergy-statistics, accessed June 18, 2019.

US Department of Agriculture and Foreign Agricultural Service

2019 World Corn Production, Consumption, and Stocks Database. Electronic document, https://apps.fas.usda. gov/psdonline/app/index.html\#/app/home, accessed June $18,2019$.

VanDerwarker, Amber M., Dana N. Bardolph, and C. Margaret Scarry

2017 Maize and Mississippian Beginnings. In Mississippian Beginnings, edited by Gregory D. Wilson, pp. 29-70. University Press of Florida, Gainesville.

Wall, Joseph S., Michael R. Young, and Kenneth J. Carpenter

1987 Transformation of Niacin-Containing Compounds in Corn during Grain Development: Relationships to Niacin Nutritional Availability. Journal of Agricultural Food Chemistry 35:752-758.

Watson, S. A.

2003 Description, Development, Structure, and Composition of the Corn Kernel. In Corn: Chemistry and Technology, 2nd ed., edited by Pamela J. White and 
Lawrence A. Johnson, pp. 69-106. American Association of Cereal Chemists, St. Paul, Minnesota.

Werth, Lindsay C.

2007 Characterization and Classification of Native American Maize Landraces from the Southwestern United States. Master's thesis, Department of Agronomy, Iowa State University, Ames.

Whiting, Alfred E.

1939 Ethnobotany of the Hopi. Museum of Northern
Arizona Bulletin No. 15. Museum of Northern Arizona, Flagstaff.

Xolocotzi, Efraím Hernández

1985 Man and Maize in the Greater Southwest. Economic Botany 39:416-430.

Submitted October 29, 2020; Revised July 13, 2021;

Accepted October 3, 2021 